\title{
$5-2014$
}

\section{Evaluation of an Inclined Gravity Settler for Microalgae Harvesting}

\author{
Zhaowei Wang \\ Cleveland State University / currently at Newland Biotech, Ltd \\ Jing Hou \\ Cleveland State University \\ Dustin Bowden \\ Cleveland State University \\ Joanne M. Belovich \\ FbfibelathfsStapted dudikersity works at: https://engagedscholarship.csuohio.edu/encbe_facpub \\ Part of the Chemical Engineering Commons
}

How does access to this work benefit you? Let us know!

\section{Publisher's Statement}

This is the accepted version of the following article: Wang, Z. , Hou, J. , Bowden, D. and Belovich, J. M. (2014), Evaluation of an inclined gravity settler for microalgae harvesting. J. Chem.

Technol. Biotechnol., 89: 714-720. , which has been published in final form at https://onlinelibrary.wiley.com/doi/abs/10.1002/jctb.4174

\section{Original Citation}

Wang Z, Hou J, Bowden D, Belovich JM. Evaluation of an inclined gravity settler for microalgae harvesting. J Chem Technol Biotechnol. 2014;89:714-720.

\section{Repository Citation}

Wang, Zhaowei; Hou, Jing; Bowden, Dustin; and Belovich, Joanne M., "Evaluation of an Inclined Gravity Settler for Microalgae Harvesting" (2014). Chemical \& Biomedical Engineering Faculty Publications. 142.

https://engagedscholarship.csuohio.edu/encbe_facpub/142

This Article is brought to you for free and open access by the Chemical \& Biomedical Engineering Department at EngagedScholarship@CSU. It has been accepted for inclusion in Chemical \& Biomedical Engineering Faculty Publications by an authorized administrator of EngagedScholarship@CSU. For more information, please contact library.es@csuohio.edu. 


\title{
Evaluation of an inclined gravity settler for microalgae harvesting
}

\author{
Zhaowei Wang, Jing Hou, Dustin Bowden and Joanne M. Belovich
}

\section{INTRODUCTION}

In recent years, interest in microalgae as a feedstock for biodiesel and aviation fuel has grown significantly. The numerous advantages of algae as a biofuel (high oil content, fast growth rate, non-arable land use) have been reviewed recently.' Algae has many commercial applications in addition to biofuel, including nutritional supplements, omega-3 fatty acids, cosmetics, and fish feed. Algae has been grown at large scale for the high-value nutritional supplement market since the 1950s, but commercial production of biofuel from auxotrophic algae, even at the pilotscale, has proven to be elusive. ${ }^{2}$

One of the main barriers to the commercial use of algae for biofuel has been the high cost of the algae harvesting process. Separation of the algae from the water is difficult due to the low algae concentration, normally less than $0.5 \mathrm{wt} \%$, and the small size of the algae cells, generally $5-10 \mu \mathrm{m}$ in diameter. An analysis of the process modeling work of Molina Grima et al. ${ }^{3}$ shows that the algae harvesting cost may comprise $15-30 \%$ of the total cost for manufacturing crude algae oil.

Systems for algae harvesting that are used at the lab scale and in the pharmaceutical and nutritional supplement industries, such as centrifugation and membrane filtration, generally become cost-prohibitive for large scale biofuel production using current technology. To be viable for large-scale biofuel production, the harvesting process must have low operating costs and be able to run in continuous mode. Centrifugation is both energy and capital intensive. ${ }^{3}$ Significant progress has been made in membrane filtration, with $80-95 \%$ reduction in energy use compared with centrifugation or froth filtration ${ }^{4}$ at the laboratory level. Electropheretic and magnetic separation techniques ${ }^{5}$ have also been developed for algae separation. These and other methods of algae harvesting have recently been reviewed. ${ }^{6}$

Most freshwater algae species are denser than water and can be harvested using gravity sedimentation. Large settling tanks have been used for algae recovery in large-scale wastewater treatment systems, ${ }^{7}$ but these systems require long retention times of 1-2 days, ${ }^{8}$ necessitating very large volumes. Conical settling tanks can reduce settling time, with $62 \%$ of algae biomass harvested in a pilot-scale unit with a residence time of $3 \mathrm{~h} .{ }^{9}$ Flocculants, such as alums, ferric chloride, and chitosan, have been used to aggregate and reduce the settling time. ${ }^{10}$ Flocculation combined with air flotation and removal using surfactants have also proven effective at the small scale. ${ }^{11}$ The costs associated with both the raw material usage, and/or separation and recovery of the flocculants, can make these methods cost-prohibitive for biofuel applications.

Inclined gravity settlers, which have been used for cell retention in mammalian cell perfusion systems and for solids removal from waste water, have significantly reduced volumes compared with tank or vertical conical settlers. ${ }^{12-14}$ The biomass recovery of the microalgae Micractinium from wastewater-containing ponds was increased 4-6-fold when using an inclined tube compared with a 
conical tank $k^{15}$ at the same ratio of volumetric flow rate to surface area. Inclined gravity settlers can be operated as either downward flow, with fluid entering the top of the settler, or upward flow, with fluid entering at the bottom of the settler. Most commercial inclined settlers used for solids removal from wastewater are upward flow, where the upward flow assists in compacting the settling solids into larger flocs along the lower plate surface. Algae are known to adhere to a variety of surfaces, and a downward flow settler may have less biomass adhesion to the lower surface because the fluid motion assists in movement of the settled solids to the outlet stream. Another potential advantage of downward flow is a reduction in settler surface area required. The operation of an inclined settler, for both upward and downward flow, can be approximated by the following equation: ${ }^{12}$

$$
F_{o}=v A \sin \theta
$$

where $F_{0}$ is the flow rate of cell suspension entering the settler, $A$ is the surface area of the settler $(=W \times L), v$ is the cell settling velocity, and $\theta$ is the angle to the vertical (Fig. 1). Upward flow settlers with mammalian cells generally have lower angles of about $30^{\circ}$ to maximize cell settling. ${ }^{12-14}$ The angle in a downward flow settler can be increased to $55^{\circ}$ without loss of efficiency in mammalian cell separation, ${ }^{16}$ resulting in an increase of capacity (i.e. $F_{0}$ ) by $64 \%$, for the same area and cell line, according to Equation (1).

The effectiveness of an inclined gravity cell for microalgae harvest is evaluated here. The effects of flow rate, outlet flow rate ratio, surface area, and biomass concentration on separation efficiency have been determined. Two freshwater microalgae species which have been investigated extensively for oil production have been selected: Scenedesmus dimorphus and Chlorella vulgaris. Scenedesmus dimorphus has a relatively high specific growth rate, up to $1.6 \mathrm{day}^{-1}$ for $S$. obliquus, a taxonomic synonym for $S$. dimorphus ${ }^{17}$ and high lipid content, up to $32 \%$ of dry biomass weight $(w / w) .{ }^{18}$ Chlorella vulgaris has a high growth rate and high lipid content, up to $52 \% .^{19}$

\section{EXPERIMENTAL}

\section{Cell lines and media}

The S. dimorphus and C. vulgaris cell lines were originally obtained from the UTEX culture collection (Austin, TX), ID\# 417 and 2714,
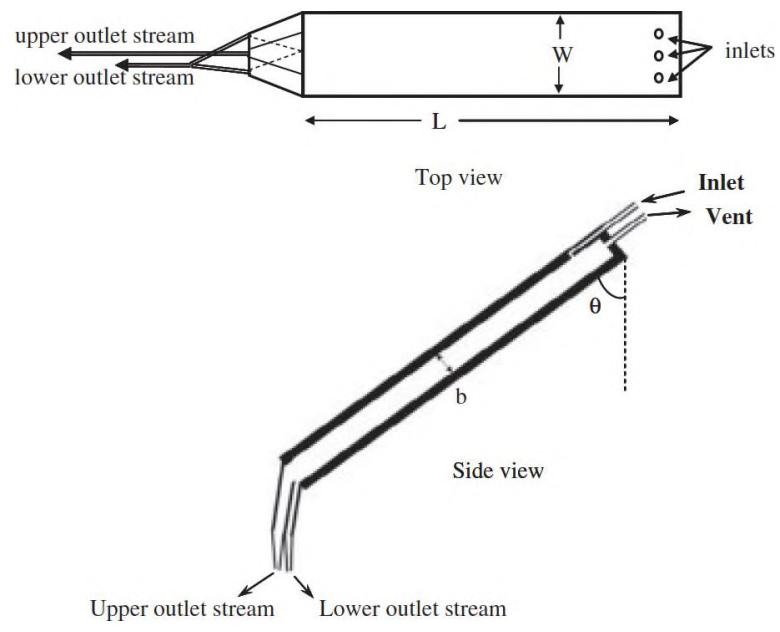

Figure 1. Schematic of the inclined gravity settler. respectively. Algae stock was thawed from liquid nitrogen (in 5\% DMSO), and maintained in $1.5 \%$ agar prepared with modified Bold's $3 \mathrm{~N}(3 \mathrm{~N}-\mathrm{BB})$ medium. The $3 \mathrm{~N}-\mathrm{BB}$ medium contained the following components per $1 \mathrm{~L}$ of DI water: $0.75 \mathrm{~g} \mathrm{NaNO}_{3}, 0.025 \mathrm{~g} \mathrm{CaCl}_{2} \cdot 2 \mathrm{H}_{2} \mathrm{O}$, $0.075 \mathrm{~g} \mathrm{MgSO}_{4} \cdot 7 \mathrm{H}_{2} \mathrm{O}, 0.075 \mathrm{~g} \mathrm{~K}_{2} \mathrm{HPO}_{4}, 0.175 \mathrm{~g} \mathrm{KH}_{2} \mathrm{PO}_{4}, 0.025 \mathrm{~g}$ $\mathrm{NaCl}, 6 \mathrm{~mL}$ trace metal stock solution (containing $0.75 \mathrm{~g} \mathrm{~L}^{-1}$ $\mathrm{Na}_{2}$ EDTA, $0.097 \mathrm{~g} \mathrm{~L}^{-1} \mathrm{FeCl}_{3} \cdot 6 \mathrm{H}_{2} \mathrm{O}, 0.041 \mathrm{~g} \mathrm{~L}^{-1} \mathrm{MnCl}_{2} \cdot 4 \mathrm{H}_{2} \mathrm{O}, 0.005$ $\mathrm{g} \mathrm{L}^{-1} \mathrm{ZnCl}_{2}, 0.002 \mathrm{~g} \mathrm{~L}^{-1} \mathrm{CoCl}_{2}$, and $\left.0.004 \mathrm{~g} \mathrm{~L}^{-1} \mathrm{NaMoO}_{4}\right)$, and $2 \mathrm{~mL}$ of each vitamin stock solution ( $\mathrm{H}$ (biotin) at $0.04 \mathrm{~g} \mathrm{~L}^{-1}, \mathrm{~B}_{1}$ (thiamine) at $1.105 \mathrm{~g} \mathrm{~L}^{-1}$, and $\mathrm{B}_{12}$ (cyanocobalamin) at $0.1575 \mathrm{~g}$

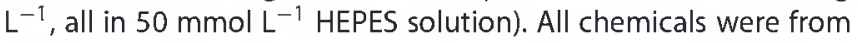
Sigma.

Seed cultures of $S$. dimorphus for growth experiments were prepared by inoculating cells from agar into a $250 \mathrm{~mL}$ Erlenmeyer flask with $3 \mathrm{~N}-\mathrm{BB}$ medium, sparged with $5 \% \mathrm{CO}_{2}$ in air at a flow rate of $0.1 \mathrm{~L} \mathrm{~min}^{-1}$, and agitated on a stir plate at room temperature. Illumination was provided by $14 \mathrm{~W}, 48^{\prime \prime}$ Accupro fluorescent bulbs on a $12 \mathrm{~h}$ on/12 h off cycle, with a measured intensity of 50-65 $\mu \mathrm{mol} \mathrm{m} \mathrm{m}^{-2} \mathrm{~s}^{-1}$ at the liquid surface maintained in a sterile hood. Bottles ( $2 \mathrm{~L}$ ) containing $3 \mathrm{~N}-\mathrm{BB}$ medium were inoculated with algae from the seed flask. The cultures were maintained at $33^{\circ} \mathrm{C}$ in a shaking water bath at about $150 \mathrm{rpm}$, and sparged with $5 \% \mathrm{CO}_{2}$ in air at a flow rate of $0.1 \mathrm{~L} \mathrm{~min}^{-1}$. Illumination was provided by seven 14 W, 24" fluorescent tubes (four Coralite Aquapro T-5/10,000K and three Accupro AFL/F14T5/14W/830) on a $12 \mathrm{~h}$ on/12 h off cycle, with a measured intensity of $168-180 \mu \mathrm{mol} \mathrm{m} \mathrm{m}^{-2} \mathrm{~s}^{-1}$ at the liquid surface. When the algae concentration reached about $2 \mathrm{gdw}$ $\mathrm{L}^{-1}$, the suspension was transferred into a bioreactor for gravity settler experiments.

The C. vulgaris cultures were maintained in the same medium and same conditions as described above, with the exception that C. vulgaris were transferred directly from agar to a $2 \mathrm{~L}$ bottle on the shaker bath to develop the inoculum for the bioreactor.

\section{Inclined gravity settlers and experimental setup}

Two gravity settlers were constructed with polycarbonate sheets as shown in Fig. 1. The small settler inner dimensions were $59 \times$ $4.5 \times 1 \mathrm{~cm}(L \times W \times b)$, with surface area of $265.5 \mathrm{~cm}^{2}$, and the large settler inner dimensions were $59 \times 9.5 \times 1 \mathrm{~cm}(L \times W \times$ b), with surface area of $560.5 \mathrm{~cm}^{2}$. The polycarbonate sheets $(3 / 8$ inch for upper and lower surfaces, $1 / 4$ inch for sides; Team Plastic, Inc., Cleveland) were assembled using Max Bond epoxy (Polymer Composites, Los Angeles). Flexible silicone tubing (Cole-Parmer, size 13) was connected to the two outlet ports and the inlet port. The settlers were autoclaved at $121^{\circ} \mathrm{C}$. The settlers were held at an angle of $55^{\circ}$ from the vertical by means of a support structure. The experimental setup is shown in Fig. 2. Flow rates through the two outlet streams were controlled via peristaltic pumps and both product streams were returned to the bioreactor. Cell suspension from the bioreactor entered the top inlet of the settler by suction. Samples were taken nearly simultaneously from the two outlet streams and from the bioreactor.

For experiments with the small settler, the algae cultures were transferred from the $2 \mathrm{~L}$ bottles to the $2.5 \mathrm{~L}$ (working volume) bioreactor (B Braun Biotech) with 3N-BB medium, agitated at 130 $\mathrm{rpm}$, and provided with air/ $\mathrm{CO}_{2}$ and light as described above. Algae cultures were maintained in a $5 \mathrm{~L}$ (working volume) bioreactor (New Brunswick) for the large settler experiments, and maintained under the same conditions as described above.

The effect of the lower outlet flow rate ratio $\left(F_{1} / F_{0}\right)$ was determined with $S$. dimorphus in the large settler, by maintaining the inlet flow rate constant at $20 \mathrm{~mL} \mathrm{~min}^{-1}$, while varying the outlet 


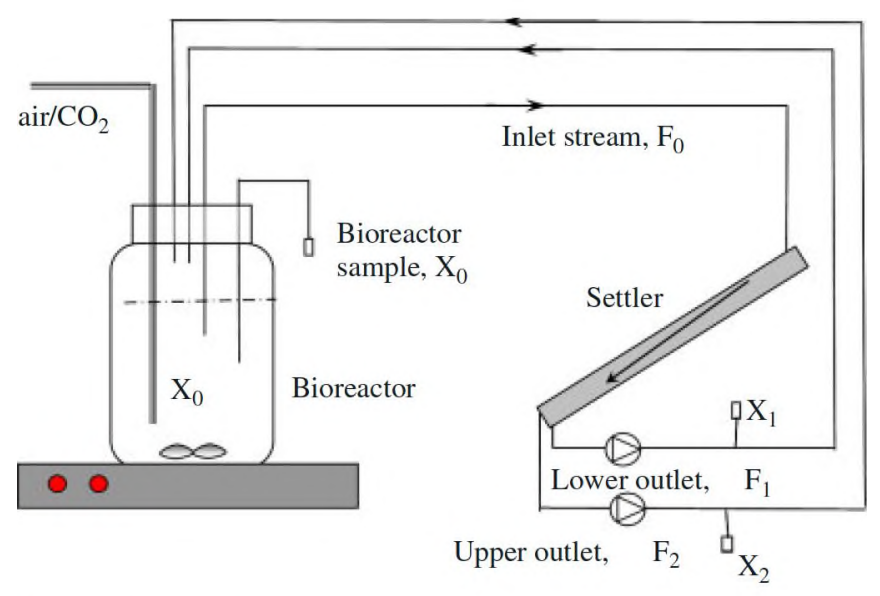

Figure 2. Setup of the gravity settler with the bioreactor.

flow rates (upper outlet/lower outlet $=16 / 4.0,17 / 3.0,18 / 2.0$, all in $\left.\mathrm{mL} \min ^{-1}\right)$. Similar experiments were conducted with $C$. vulgaris using the small settler, and inlet flow rate of $7.8 \mathrm{~mL} \mathrm{~min}^{-1}$, while varying the outlet flow rates (upper outlet/lower outlet $=6.4 / 1.4$, 7.0/0.8, 7.4/0.4, all in $\mathrm{mL} \mathrm{min}^{-1}$ ). The effect of inlet flow rate was determined with the small settler for both 5 . dimorphus and C. vulgaris. The inlet flow rate was varied $(2.22,7.78,13.33 \mathrm{~mL}$ $\mathrm{min}^{-1}$ ), while $F_{1} / F_{0}$ was kept constant at 0.1 (upper outlet/lower outlet $=2.00 / 0.22,7.00 / 0.78,12.00 / 1.33 \mathrm{~mL} \mathrm{~min}^{-1}$, respectively). Similar experiments were conducted with $S$. dimorphus and the large settler, with inlet flow rates varied $\left(4.7,16.4,28.7 \mathrm{~mL} \mathrm{~min}^{-1}\right)$, while $F_{1} / F_{0}$ was kept constant at 0.1 (upper outlet/lower outlet= $4.2 / 0.47,14.8 / 1.64,25.8 / 2.86 \mathrm{~mL} \mathrm{~min}^{-1}$, respectively).

The effect of biomass concentration on the settler performance was determined by supplementing the $S$. dimorphus in the $2.5 \mathrm{~L}$ bioreactor with additional algae suspension cultured in $2 \mathrm{~L}$ bottles, which had been allowed to settle and some of the supernatant withdrawn, to achieve a total biomass concentration in the $2.5 \mathrm{~L}$ bioreactor of $4.5-5.2 \mathrm{gdw}^{-1}$.

For each new set of operating parameters, samples were taken from the inlet and outlet streams approximately every $6 \mathrm{~h}$, until an approximate steady state was reached. Samples were then taken every $24 \mathrm{~h}$, for $3-7$ days.

Settling velocity measurements of $S$. dimorphus were obtained using a settling column as described previously. ${ }^{20}$ The algae were cultured in a $5 \mathrm{~L}$ New Brunswick BioFlo 115 bioreactor in 3N-BB media, with $24 \mathrm{~h}$ light, in continuous mode. Samples of $50 \mathrm{~mL}$ were collected from the harvest stream at dilution rates of 0.3-0.4 $\mathrm{day}^{-1}$. Cell suspensions were diluted with media to $A_{600}$ of $0.2-0.3$ and then added to the settling column, where the cell suspensions were allowed to settle for $3 \mathrm{~h}$. Biomass concentrations in the upper and lower chambers of the settling column were determined using both absorbance $(600 \mathrm{~nm})$, to obtain a population-average settling velocity, and manual cell counts of single cells, doubles, triples, and quads using a hemocytometer, to obtain the settling velocity of each of these subpopulations.

\section{Analytical methods}

Culture absorbances were measured spectrophotometrically at $600 \mathrm{~nm}$ as indicators of biomass concentration. Previous work ${ }^{21}$ has shown that algae biomass concentration is linearly related to $A_{600}$, up to $A_{600}=1.0$, with slope of $0.50 \pm 0.03 \mathrm{gdw} \mathrm{L}^{-1} \mathrm{~A}_{600}{ }^{-1}$. Samples with higher biomass concentrations were diluted with $3 \mathrm{~N}-\mathrm{BB}$ media to ensure $\mathrm{A}_{600}<1.0$.
The separator effectiveness is quantified using two metrics: the concentration ratio and biomass recovery ratio. The concentration ratio, $C$, is defined as the ratio of biomass concentration in the lower outlet stream, $A_{1}$, relative to the biomass concentration in the inlet stream, $A_{0}$, given by:

$$
C=\frac{A_{1}}{A_{0}}
$$

The biomass recovery ratio, $R$, is defined as the quantity of biomass in the lower outlet stream relative to the input stream, given by:

$$
R=\frac{A_{1} F_{1}}{A_{0} F_{0}}
$$

where $F_{1}$ is the flow rate of the lower outlet stream and $F_{0}$ is the flow rate into the settler from the bioreactor. The total biomass recovery, $R_{t}$, is defined as the percentage of biomass entering the settler that exits the settler in both outlet streams, given by:

$$
R_{t}=\frac{A_{1} F_{1}+A_{2} F_{2}}{A_{0} F_{0}} \times 100 \%
$$

Statistical analysis was performed using student's t-test (Excel), using a two-tailed distribution with confidence level of $95 \%$.

\section{RESULTS}

The effects of the ratio of the lower outlet to the inlet stream on recovery rate and concentration factor are shown in Fig. 3. The recovery (Fig. 3(a)) of biomass increases significantly with the flow rate ratio for $C$. vulgaris. This relationship is not statistically significant with the $S$. dimorphus $(P>0.05)$, where the higher $S$. dimorphus biomass concentration in the lower outlet stream is balanced by the lower flow rate of this stream at lower $F_{1} / F_{0}$ ratios. For both cell lines, the biomass concentration in the recovered stream (lower outlet) increases significantly as the lower outlet flow rate decreases (Fig. $3(\mathrm{~b}) ; P<0.001$ ). For $S$. dimorphus, the biomass concentration can be increased 3.6 -fold relative to the inlet concentration, with no reduction of biomass recovery, by operating at the lowest flow ratio $\left(F_{1} / F_{0}=0.1\right)$. With $C$. vulgaris, a trade-off occurs between increasing biomass concentration (almost 4 -fold) while decreasing biomass recovery to $20 \%$ at the lowest flow ratio.

Since the flow rate ratio of $F_{1} / F_{0}=0.1$ resulted in optimal settler performance (maximum concentration and recovery ratios) using S. dimorphus, this ratio was used in investigating the effects of inlet flow rate and inlet biomass concentration on settler performance in subsequent experiments (Fig. 4). As the total flow rate through the settlerincreases, the concentration ratio decreases $(P<0.01)$, due to the reduced residence time of both fluid and cells at the higher flow rate. Since $F_{1} / F_{0}=0.1$ in these experiments, according to Equation (3), the recovery ratio is directly proportional to the concentration ratio by a factor of 0.1 , and thus this outcome is not shown. Except at the lowest flow rate, $C$. vulgaris demonstrated significantly lower concentration and recovery ratios than $S$. dimorphus $(P<0.001)$. At the lowest flow rate, the concentration factor of the $C$. vulgaris is $24 \%$ lower than that of S.dimorphus, but with a $P=0.056$. A 5 -fold increase in the concentration of biomass in the bioreactor, and thus in the inlet stream, had negligible effect on settler performance in harvesting the $S$. dimorphus $(P>0.3)$. 

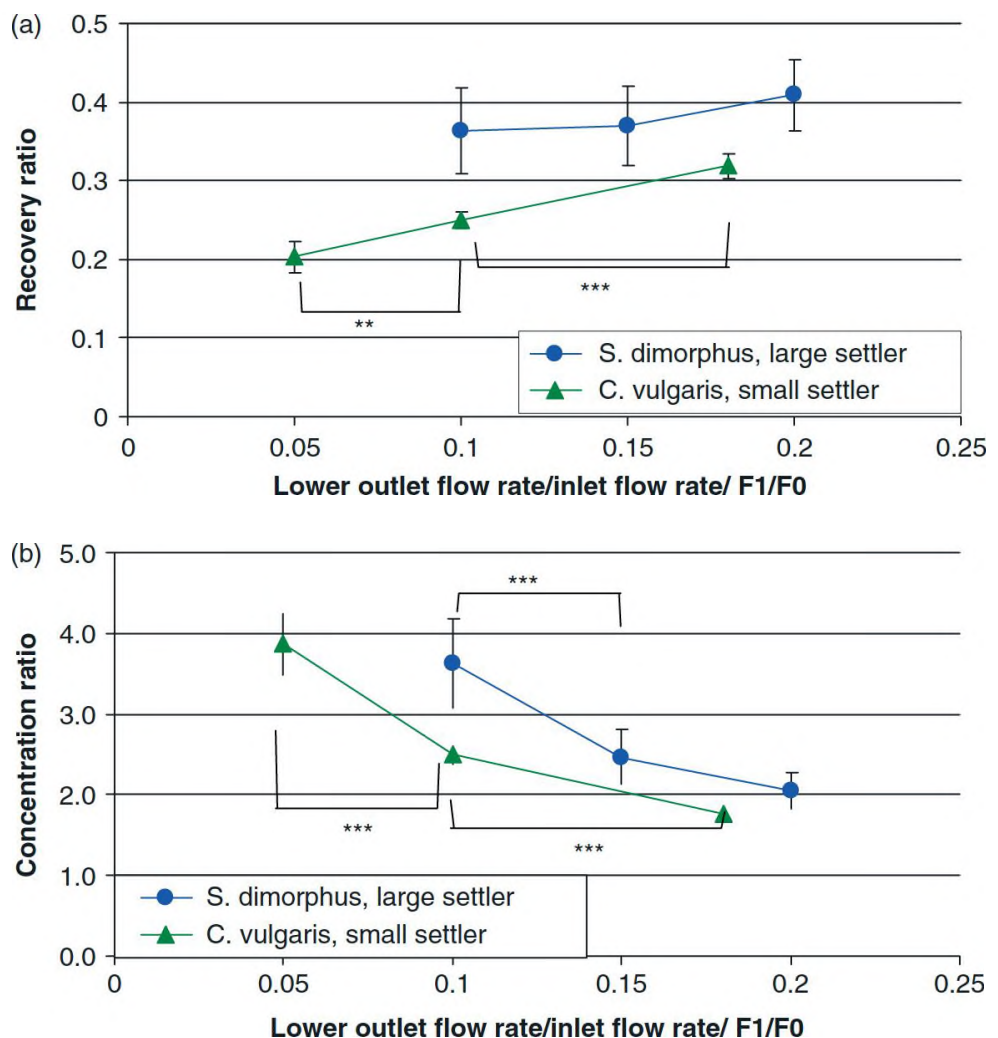

Figure 3. Effect of the ratio of lower outlet flow rate to inlet flow rate $\left(F_{1} / F_{0}\right)$ on settler performance, using the large settler $\left(566.4 \mathrm{~cm}^{2}\right)$ and inlet flow rate of $20 \mathrm{~mL} \mathrm{~min}{ }^{-1}$ with $S$. dimorphus and using the small settler $\left(260.5 \mathrm{~cm}^{2}\right)$ and an inlet flow rate of $7.8 \mathrm{~mL} / \mathrm{min}$ with C. vulgaris. The biomass concentration in the inlet stream varies between $2.4-3.0 \mathrm{gdw} \mathrm{L} \mathrm{L}^{-1}$ for $S$. dimorphus, and $0.5-1.2 \mathrm{gdw} \mathrm{L}^{-1}$ for $C$. vulgaris. The symbols represent the mean and standard deviations; $\mathrm{n}=4-9$ for S. dimorphus and $\mathrm{n}=5$ for $C$. vulgaris. " "***" indicates $P<0.01 ;{ }^{\prime \prime * * * *}$ indicates $P<0.001$.

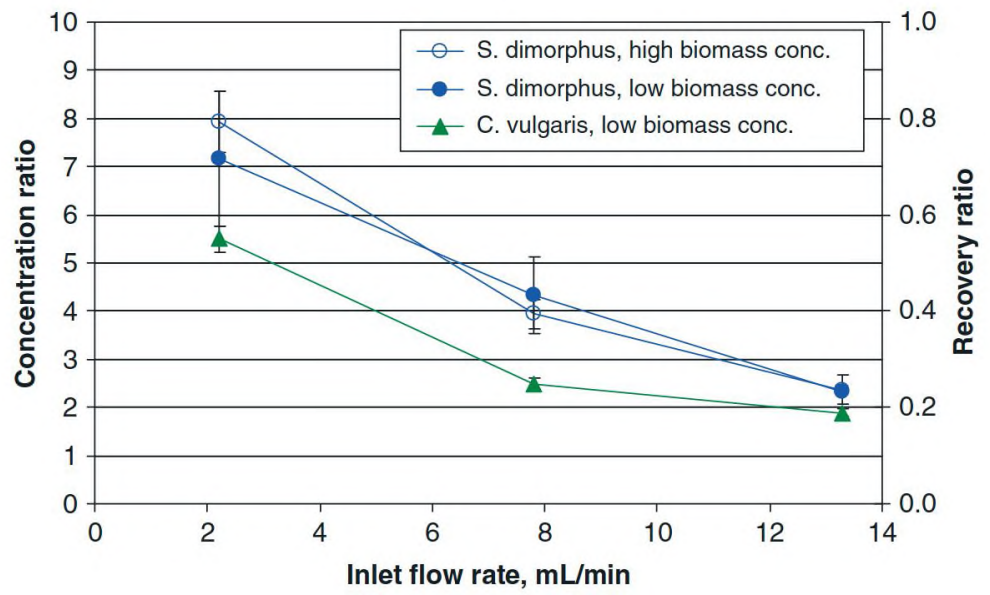

Figure 4. Effect of inlet flow rate on small $\left(260.5 \mathrm{~cm}^{2}\right)$ settler performance using $S$. dimorphus and $C$. vulgaris. The ratio of the lower outlet flow rate to the inlet flow rate $\left(F_{1} / F_{0}\right)$ is kept constant at 0.1 . For $S$. dimorphus, the low biomass concentration was $0.8-1.1 \mathrm{gdw} \mathrm{L}^{-1}$ in the inlet stream; the high biomass concentration was $4.5-5.2 \mathrm{gdw} \mathrm{L} \mathrm{L}^{-1}$. The inlet stream biomass concentration of $C$. vulgaris was $0.5-0.8 \mathrm{gdw} \mathrm{L}^{-1}$. The values represent the mean and standard deviations of $n=5$ measurements for $C$. vulgaris, $n=3-7$ for $S$. dimorphus. Note that the error bars are too small to be seen in some cases.

The data in Fig. 4 for the S. dimorphus at the low biomass concentration are replotted in Fig. 5, where the inlet flow rates are scaled to the settler surface area. Similar experiments were then conducted with the large settler to investigate the scalability of the settler design. Surprisingly, the large settler actually exhibits slightly improved performance compared with the small settler, with greater concentration factor and biomass recovery, although the difference is only significant at the highest flow rate/area value of $0.05 \mathrm{~cm} \mathrm{~min} \mathrm{~m}^{-1}\left(P=1.8 \times 10^{-6}\right)$. This slight improvement might be caused by boundary effects. The small settler has a smaller cross-section than the large settler, and thus exhibits greater boundary effects, which increases the turbulence of the fluid flow and disrupts the settling process of the cells.

The total biomass recovered in both outlet streams, calculated using Equation (4) from all the experiments, is shown in Fig. 6. Of the rates of biomass entering the settler from all the experiments, 


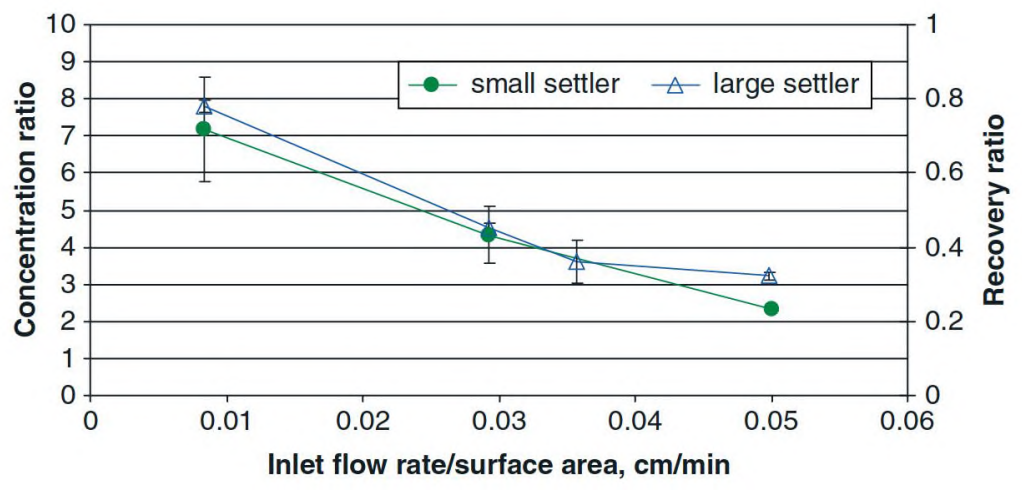

Figure 5. Scalability of settler with S. dimorphus, using the small and large settlers, with surface areas of $265.5 \mathrm{~cm}^{2}$ and $560.5 \mathrm{~cm}^{2}$, respectively. The ratio of the lower outlet flow rate to the inlet flow rate is constant at 0.1 . The biomass concentration in the inlet stream varied between 0.8 and $1.5 \mathrm{gdw} \mathrm{L}^{-1}$. The values represent the mean and standard deviations of $n$ measurements, with $n=5-9$ for large settler, $4-7$ for small settler.

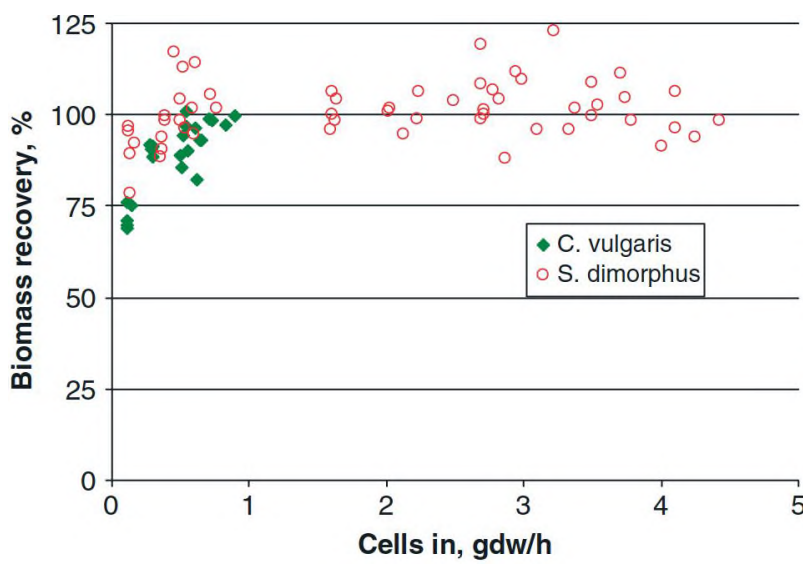

Figure 6. Total biomass recovered $\left(R_{t}\right)$ from the settler during continuous operation, from all experiments using both cell lines.

$89 \pm 10 \%$ of C. vulgaris and $101 \pm 8 \%$ of $S$. dimorphus (mean \pm standard deviation) were recovered, indicating that little, if any, accumulation of biomass in the settler occurred during the course of the experiment. The system was operated continuously for up to 3 weeks at a time, with minimal visible accumulation of the algae in the settler.

Scenedesmus dimorphus cultures exist in single cells, doubles, triplets, and quadruplets (Fig. 7 (b)-(d)). The cultures are normally dominated by quadruplets in actively growing cultures, which constitute $87 \pm 6 \%(n=4)$ of the flocs, and thus the average settling velocity of the culture $\left(0.79 \pm 0.12 \mathrm{~cm} \mathrm{~h}^{-1}\right)$, as measured by $A_{600}$, is not significantly different from the settling velocity of the quads $\left(0.74 \pm 0.24 \mathrm{~cm} \mathrm{~h}^{-1}\right)$, as measured using cell counts in the hemocytometer (Fig. 7(a)). As expected, the settling velocity of the population of cell quads is greater than that of singles and doubles. However, the settling velocity of the triplets was close to that of the quads, which could be explained by the observation that some triplets are larger in size than some quads, as shown in Fig. 7(c).

The expected capacity of the settler for harvesting algae, as defined by $F_{0} / A$, was calculated using the population-averaged settling velocity of the $S$. dimorphus culture $\left(0.79 \mathrm{~cm} \mathrm{~h}^{-1}\right)$, and the approximate design equation (Equation (1)), to be $0.011 \mathrm{~cm}^{3}$ $\mathrm{cm}^{-2} \mathrm{~min}^{-1}$. From interpolation of the experimental results at this flow rate/surface area ratio (Fig. 5), the expected recovery ratio is 0.72 . This result indicates that the use of Equation (1) and the measured settling velocity to determine the operating conditions would yield $72 \%$ efficiency in terms of biomass recovery, and a 7-fold increase in biomass concentration.

\section{DISCUSSION}

The gravity settler successfully concentrated $S$. dimorphus up to 8 -fold and $C$. vulgaris up to 5 -fold (Fig. 4), resulting in a concentrated product stream concentration of $42 \mathrm{gdw} \mathrm{L}^{-1}$ in some circumstances. The results in Fig. 4 also indicate that the separation efficiency is nearly independent of the inlet stream biomass concentration, between 1 and $5 \mathrm{gdw} \mathrm{L}^{-1}$, over the range of inlet flow rates tested. Higher particle concentrations can be expected to result in greater separation efficiency if the particles tend to aggregate and thus settle faster. In this case, however, increased cell aggregation was not observed at the higher concentration, leading to similar separation efficiencies. Algae concentrations in ponds can be as low as $1-2 \mathrm{gdw} \mathrm{L}^{-1}$ due to light limitations. It is envisioned that the algae suspension from a pond would be concentrated using two stages of the settler in series, with each stage achieving a 7-8-fold increase in biomass concentration, for an overall increase in concentration of 49-fold to 64-fold. A 49-fold increase in biomass concentration with two stages results in the removal of $98 \%$ of the water from the initial cell suspension and an overall biomass recovery of $49 \%$, using data from Fig. 4. The upper outlet stream, containing the removed water, contains unused nutrients as well as some biomass. This stream would most likely be recycled to the culture system to contribute to cell growth and to minimize fresh water and nutrient usage. In a large-scale implementation, the gravity settler could be used first to inexpensively remove and recycle $98 \%$ of the water in the cell suspension, followed by processing in another type of unit operation to further concentrate the algae and extract the oil. We estimate the energy cost of algae dewatering using a two-stage gravity settler, followed by a centrifuge, to be $\$ 0.19$ gall $^{-1}$ crude algae oil, using assumptions: $\$ 0.08$ per kWh electricity, biomass of $20 \mathrm{wt} \%$ oil, $80 \%$ oil recovery, and $\$ 0.0048 \mathrm{kWh}$ per gall fluid through the centrifuge. ${ }^{3}$

In most separation processes, there is a trade-off between purity and recovery in the product stream. This trade-off is visible for C. vulgaris, but not for $S$. dimorphus, over the range of flow rates tested (Fig. 3(a) and (b)). It is possible that at ratios of $F_{1} / F_{0}<0.1$, the recovery of $S$. dimorphus may decrease even as the concentration ratio further increases. 

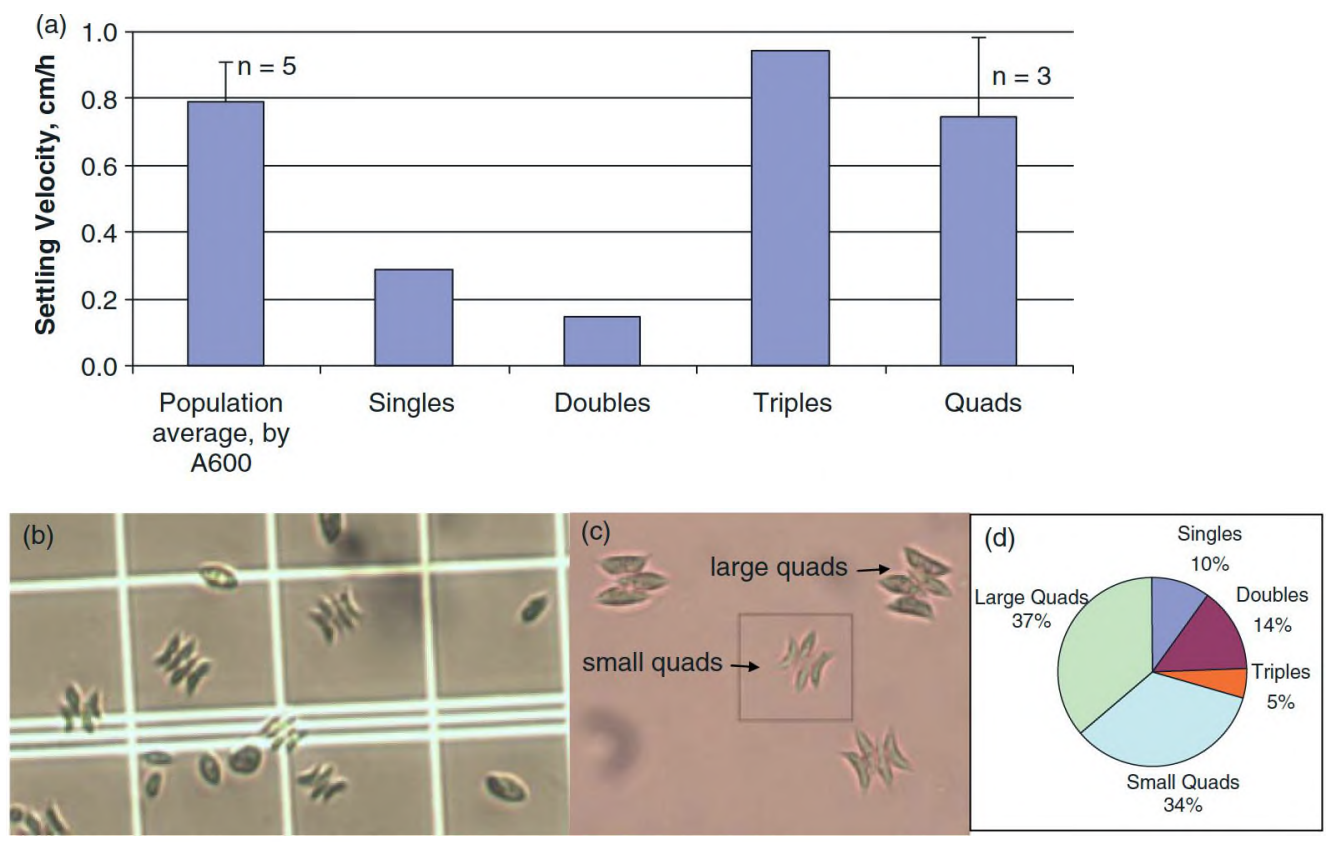

Figure 7. (a) Settling velocity measurements of the subpopulations of $S$. dimorphus, as measured using the hemocytometer, and the population average, measured using absorbance $\left(A_{600}\right)$; mean $\pm S E M, n=$ number of samples. Settling velocities of singles, doubles, and triples were reported for only one sample (shown in (d)), in which there were enough cells within these subpopulations in the samples to be counted accurately. (b), (c) Images of cells from the sample, highlighting the difference between the 'small quads' and the 'large quads'. (d) Distribution of the subpopulations within a S. dimorphus sample, before settling, determined visually in the hemocytometer.

Maximum biomass recovered occurred at the lowest flow rates tested here, $0.01 \mathrm{~cm}^{3} \mathrm{~cm}^{-2} \mathrm{~min}^{-1}$ ), yielding $55 \%$ recovery of $C$. vulgaris and $70-80 \%$ recovery of S. dimorphus (Fig. 4). At these conditions, the residence time in the settler is approximately 2 $\mathrm{h}$. These results are similar to that obtained with the settling of colonies of Micractinium in upward-flow tubes, in which biomass recoveries up to $80 \%$ were achieved at 0.2 gall min $^{-1} \mathrm{ft}^{-2}$ overflow rate, with recoveries decreasing as the flow rate increased. ${ }^{15}$ Note that those colonies had diameters of roughly $60 \mu \mathrm{m}$, which is much larger than the colonies of 5 . dimorphus and C. vulgaris evaluated here. Biomass recovery of $63 \%$ was achieved with conical settlers with residence times of $3 \mathrm{~h},{ }^{9}$ with populations comprised predominantly of Scenedesmus sp., Microactinium sp., Pediastrum sp., and Ankistrodesmus sp.). This separation was also assisted by the presence of the larger flocs, such as the Microactinium and the Pediastrum, where the latter can exist in colonies up to $200 \mu \mathrm{m}$ in size.

The near overlap of the separation efficiency curves for the two different sizes of settlers (Fig. 5) indicates that for a specified separation efficiency, the surface area of the settler scales linearly with the flow rate of the stream to be processed, with maximum performance at the minimum flow rate/area tested here $\mathbf{0 . 0 1}$ $\mathrm{cm}^{3} \mathrm{~cm}^{-2} \mathrm{~min}^{-1}$ ). This ratio, along with Equation (1), can be used for approximate scale-up calculations, but many more tests with larger settlers will need to be performed to determine the validity of this ratio for much larger systems. Also, at much larger flow rates, area can be increased by both increasing plate width, length, and number of plates stacked together (to reduce the footprint required). While there has been some previous experimentation on the best length-to-tube diameters ${ }^{15}$ for Microactinium separation, the optimal length-to-width ratio and its relationship to flow rate and cell type can be best determined by means of detailed particle/fluid modeling. Other design parameters will also impact separation performance, such as the angle of operation and material of construction, and should be further investigated.
Greater variation was observed in measurements of separation efficiency with the $S$. dimorphus cultures compared to $C$. vulgaris (Figs 3 and 4), most likely due to the greater variation in cell aggregate size in the $S$. dimorphus cultures, which exist in singles, doublets, and quads, while the C. vulgaris cultures are primarily composed of individual cells. The results presented here indicate that S. dimorphus was harvested more efficiently than $C$. vulgaris using the inclined gravity settler. Separation capacity is directly proportional to settling velocity (Equation (1)), and according to Stoke's Law, settling velocity is proportional to the square of the particle diameter and linearly proportional to difference between cell and fluid density. While the densities of the two cell lines were not measured here, the lipid contents of the two cell lines were nearly the same (data not shown), suggesting that the observed difference in separation efficiency was due more to the difference in particle diameter and shape rather than a difference in cell density. In large-scale practice, optimization of culture conditions to maximize lipid content may reduce cell density which can negatively affect separation efficiency. The lipid content, density, shape, and size of cell aggregates can vary significantly based on culture conditions, such as nutrient availability (especially nitrogen), and culture age, which affect settling velocity. Therefore, the measurement of settling velocity for the given set of culture conditions is recommended a priori for determination of optimum operating conditions.

\section{ACKNOWLEDGEMENTS}

Funding from the Ohio Plant Biotechnology Consortium is gratefully acknowledged. The polycarbonate sheets used to construct the settlers were graciously donated by Team Plastic, Inc. (Cleveland, $\mathrm{OH})$. 


\section{REFERENCES}

1 Avagyan $A B$, New design and build biological system through the use of microalgae addressed to sustainable development. J Environ Protect 1:183-200 (2010).

2 Hall CAS and Benemann JR, Oil from Algae? BioScience 61:741-742 (2011).

3 Molina Grima E, Belarbi EH, Acien Fernandez FG, Robles Medina A and Chisti $Y$, Recovery of microalgal biomass and metabolites: process options and economics. Biotech Adv 20:491 -515 (2003).

4 Bhave R, Kuritz T, Powell L and Adcock D, Membrane-based energy efficient dewatering of microalgae in biofuels production and recovery of value added co-products. Environ Sci Technol 46:5599-5606 (2012).

5 Xu L, Guo C, Wang F, Zheng $S$ and Liu CZ, A simple and rapid harvesting method for microalgae by in situ magnetic separation. Bioresource Technol 102:10047-10051 (2011).

6 Uduman N, Qi Y, Danquah MK, Forde GM and Hoadley A, Dewatering of microalgal cultures: a major bottleneck to algae-based fuels. $J$ Renew Sustain Energy 2:1 - 14 (2010).

7 Brennan $L$ and Owende $P$, Biofuels from microalgae - a review of technologies for production, processing, and extractions of biofuels and co-products. Renew Sustain Energy Rev 14:557-577 (2010).

8 Park JBK, Craggs RJ and Shilton AN, Recycling algae to improve species control and harvest efficiency from a high rate algal pond. Water Res 45:6637-6649 (2011).

9 Park JBK and Craggs RJ, Wastewater treatment and algal production in high rate algal ponds with carbon dioxide addition. Water SCi Technol 61:633-639 (2010).

10 Divakaran $\mathrm{R}$ and Sivasankara Pillai VN, Flocculation of algae using chitosan. J App/Phycol 14:419-422 (2002).
11 Chen YM, Liu JC and Ju YH, Flotation removal of algae from water. Colloids Surf B: Biointerfaces 12:49-55 (1998).

12 Batt B, Davis R and Kompala D, Inclined sedimentation for selective retention of viable hybridomas in a continuous suspension bioreactor. Biotechnol Prog 6:458-464 (1990).

13 Davis $\mathrm{RH}$, Lee $\mathrm{CY}$, Batt $\mathrm{BC}$ and Kompala DS, Cell separations using differential sedimentation in inclined settlers, in Cell Separation Science and Technology, ed by Kompala DS. American Chemical Society, $113-127$ (1991).

14 Searles J, Todd P and Kompala DS, Viable cell recycle with an inclined settler in the perfusion culture of suspended recombinant Chinese hamster ovary cells. Biotechnol Prog 10:198-206 (1994).

15 Nurdogan $\mathrm{Y}$ and Oswald WJ, Tube settling of high-rate pond algae. Water Sci Technol 33:229-241 (1996).

16 Wang Z, Two approaches for cell retention in perfusion culture systems. Doctoral dissertation, Cleveland State University (2009).

17 Yang $\mathrm{Y}$ and Gao K, Effects of $\mathrm{CO}_{2}$ concentrations on the freshwater microalgae, Chlamydomonas reinhardtii, Chlorella pyrenoidosa and Scenedesmus obliquus, (Chlorophyta). J Appl Phycol 00:1-11 (2003).

18 Shen $Y$, Pei $Z$, Yuan $W$ and Mao $E$, Effect of nitrogen and extraction method on algae lipid yield. Int J Agric Biol Eng 2(1):51 - 57 (2009).

19 Widjaja A, Chien CC and Ju YH, Study of increasing lipid production from fresh water microalgae Chlorella vulgaris. J Taiwan Inst Chem Eng 40:13-20 (2009).

20 Wang $Z$ and Belovich J, A simple apparatus for measuring cell settling velocity. Biotechnol Prog 26:1361-1366 (2010).

21 Kanani B, Lipid production by Scenedesmus dimorphus: comparison of extraction techniques and effect of sodium nitrate concentration. MS thesis, Cleveland State University (2013).

Post-print standardized by MSL Academic Endeavors, the imprint of the Michael Schwarts Library at Cleveland State University, 2018 